\title{
Long Term Evaluation of AGV Implantation in Post PK Glaucoma
}

\author{
Anita Panda*, Sasikala NK, Jaya Prakash V, Tanuj Dada, Abhiyan Kumar and Succhitra \\ All India Institute of Medical Sciences, India
}

Submission: February 20, 2017; Published: March 27, 2017

*Corresponding author: Anita Panda, Vasant Kunj, New Delhi 110070, India, Email: anitap492004@yahoo.com

\section{Introduction}

Glaucoma after penetrating keratoplasty (PK) is an important cause of graft failure besides loss of vision due to glaucomatous optic atrophy. Causes of post PK glaucoma are multifactorial [1] such as increased post-op inflammation due to synechiolysis/pupillopasty, combined with cataract extraction and or vitrectomy, retained viscoelastic, tight suturing causing tissue compression, large graft size, long suture bites, peripheral anterior synechiae and prolonged use of steroids. Management includes medical therapy and in refractory cases surgical interve. The present study aims to describe long-term outcomes of Ahmed Glaucoma Valve (AGV) implantation in Post Keratoplasty glaucoma performed at a Tertiary Eye Centre.

All subjects with Post PK Glaucoma who had undergone AGV implantation with a follow-up of minimum 5 years were evaluated. Preoperative antiglaucoma medication continued postoperatively and titrated according to the need. Surgical steps followed same in all except plate was covered either by conjunctiva or by scleral patch. Before starting the surgery, priming of the tube was done (Figure 1). After entering AC the tube was inserted and cut at desired length and the plate was covered. Clinical photographs were taken at different time period of time (Figure 2-4).

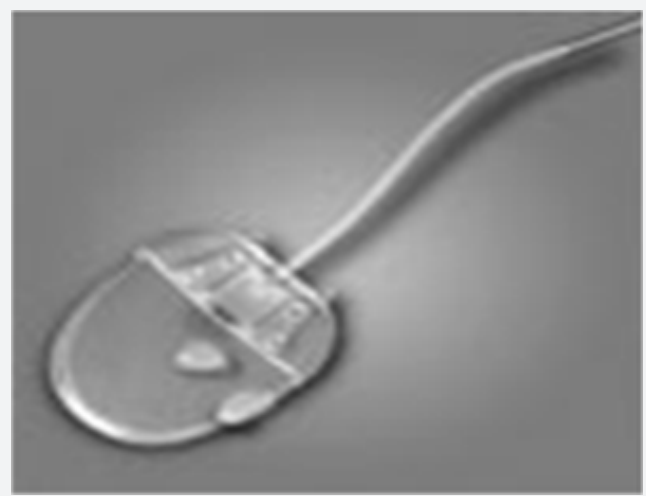

Figure 1: Priming the valve.
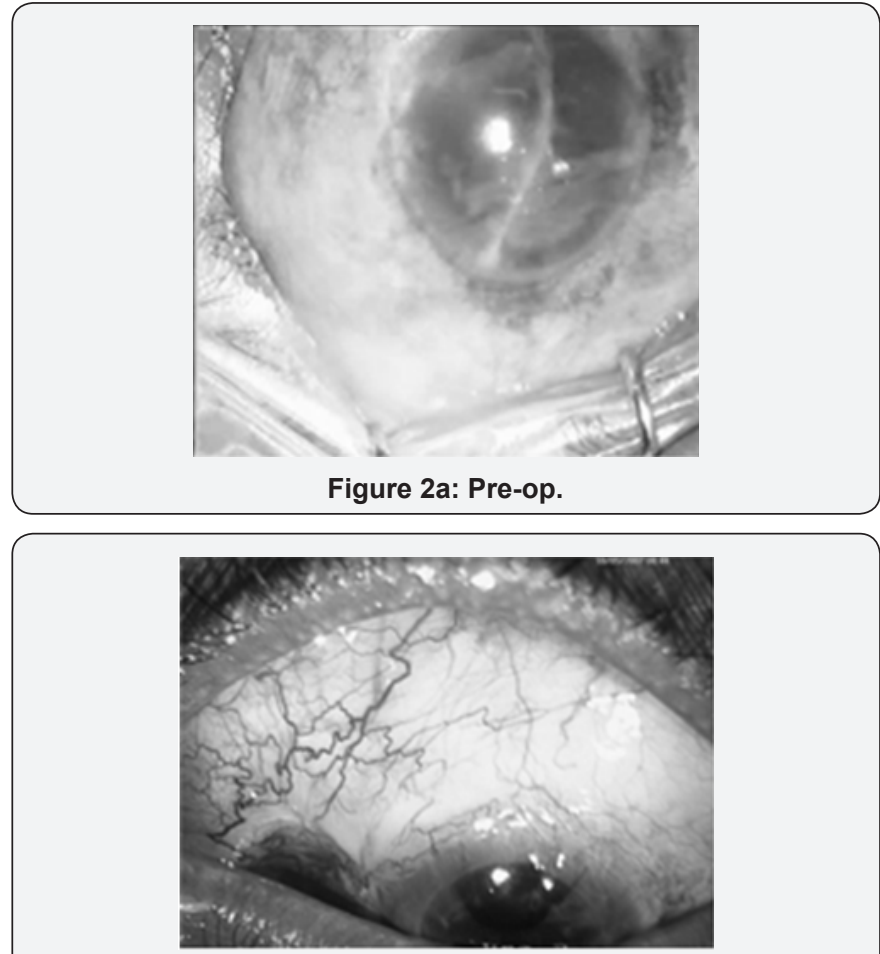

Figure 2b: Post PK AGV showing plate site over sclera.

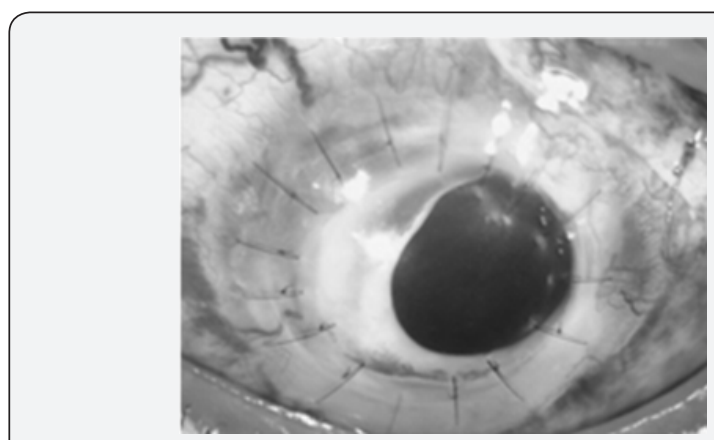

Figure 3: Post PK AGV after 5 years Post PK AGV showing plate site and tube inside AC. 


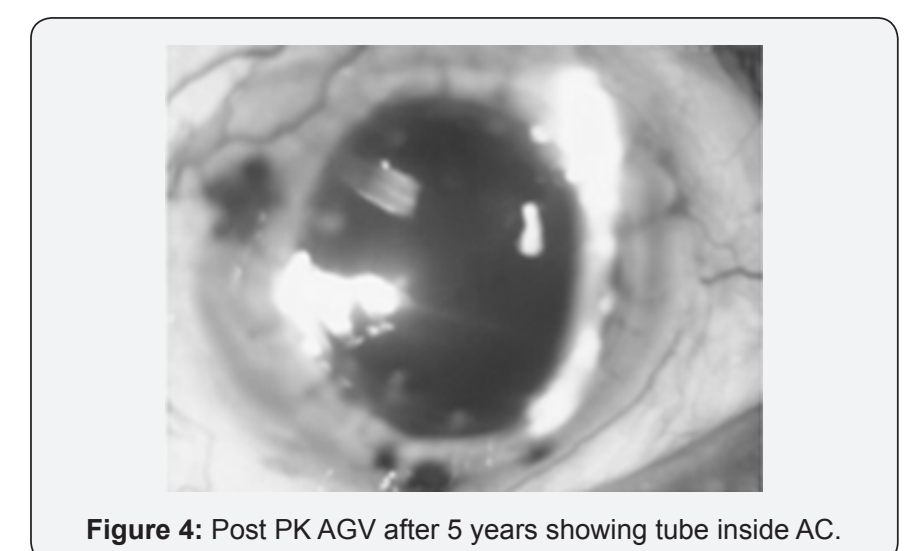

Figure 4: Post PK AGV after 5 years showing tube inside AC.

Of 32 eyes, the IOP decreased from a mean preoperative value of $32.8 \pm 3.6 \mathrm{mmHg}$ to $20.0 \pm 8.6 \mathrm{mmHg}$ at last visit. The number of medications decreased from $3.2 \pm 0.8$ preoperatively to $2.2 \pm 1.2$ postoperatively. Cumulative qualified success was achieved in $72 \%$ of eyes. The common complication was focal endothelial corneal decompensation at the site of tube-cornea touch.

\section{Discussion}

Management of Post PK glaucoma includes topical antiglaucoma medications and surgical options [1-3]. Medical management alone is not sufficient to control the Pressure besides its own hazards such as corneal decompensation, dry eye, CME in aphakic, psedophakic eyes, and recurrence of herpetic infection and depression. A result of Trabeculectomy in such eyes often fails. The valve helps to minimize postoperative hypotony and its associated complications.

\section{Conclusion}

AGV implantation with adjunctive topical anti-glaucoma drops controlled IOP in approximately $72 \%$ of eyes with Post PK glaucoma.

\section{References}

1. Goldberg DB, Schanzlin DJ, Brown SI (1981) Incidence of increased intraocular pressure after keratoplasty. Am J ophthalmol 92(3): 372377.

2. Ayyala RS, Pieroth L, Vinals AF, Goldstein MH, Schuman JS, et al. (1998) Comparision of mitomycin-C trabeculectomy, glaucoma drainage device implantation and laser neodymium YAG cyclophotocoagulation in the management of intractable glaucoma after penetrating keratoplasty. Ophthalmology 105(8): 1550-1555.

3. Panda A, Prakash VJ, Dada T, Gupta AK, Khokhar S, et al. (2011) Ahmed glaucoma valve in post-penetrating-keratoplasty glaucoma: a critically evaluated prospective clinical study. Indian J Ophthalmol 59(3): 185189.

Your next submission with Juniper Publishers will reach you the below assets

- Quality Editorial service

- Swift Peer Review

- Reprints availability

- E-prints Service

- Manuscript Podcast for convenient understanding

- Global attainment for your research

- Manuscript accessibility in different formats

( Pdf, E-pub, Full Text, Audio)

- Unceasing customer service

Track the below URL for one-step submission https://juniperpublishers.com/online-submission.php 